\title{
THE INFLUENCE OF BENTONITE AND MONTMORILLONITE ADDITION ON THE THERMAL DECOMPOSITION OF NOVEL POLYURETHANE/ORGANOCLAY NANOCOMPOSITES
}

\author{
Jelena Pavličević1, Milena Špírková ${ }^{2}$, Oskar Bera ${ }^{1}$, Mirjana Jovičić1, \\ Katalin Mészáros Szécsényi ${ }^{3}$, Jaroslava Budinski-Simendić ${ }^{1}$ \\ ${ }^{1}$ University of Novi Sad, Faculty of Technology, Bulevar cara Lazara 1, \\ 21000 Novi Sad, Republic of Serbia \\ ${ }_{2}^{2}$ Institute of Macromolecular Chemistry AS CR, v.v.i., Heyrovského nám. 2, \\ 16206 Prague, Czech Republic \\ ${ }^{3}$ University of Novi Sad, Faculty of Sciences, Trg Dositeja Obradovića 2, \\ 21000 Novi Sad, Republic of Serbia
}

Polycarbonate-based polyurethane (PC-PUs) hybrid materials were obtained by the addition of organically modified bentonite and montmorillonite $(1 w / w \%)$. PC-PUs and their nanocomposites were prepared using prepolymerization with two polycarbonate diols (both of $M_{\mathrm{r}}$ ca 1000) differing in chain constitution, hexamethylene-diisocyanate and 1,4-butane diol (chain extender) as starting components. All samples contained the same hard-segment content $(30 \mathrm{w} / \mathrm{w} \%)$. Thermogravimetry coupled with differential scanning calorimetry (TG-DSC) was performed to obtain information about the organoclays addition on the thermal stability of the prepared polyurethane elastomers. The effect of bentonite and montmorillonite nanofillers on the decomposition pattern has been evaluated. By deconvolution of derivative thermogravimetric (DTG) curves, it has been found that the thermal decomposition of polyurethane samples takes place in three overlapping processes. Degradation kinetic parameters (activation energy and reaction order) were calculated on the basis of thermal data obtained at only one heating rate.

Keywords: polycarbonate-based polyurethane nanocomposites; layered silicates; DTG; thermal stability

\section{ВЛИЈАНИЕ НА ДОДАВАЊЕТО БЕНТОНИТ И МОНТМОРИЛОНИТ ВРЗ ТЕРМИЧКОТО РАЗЛОЖУВАЊЕ НА НОВИ ПОЛИУРЕТАНСКИ/ОРГАНОГЛИНЕНИ НАНОКОМПОЗИТИ}

Полиуретански (PC-PUs) хибридни материјали базирани на поликарбонати се добиени со додавање органски модифицирани бентонит и монтморилонит (1 w/w\%). PC-PUs и нивните нанокомпозити беа подготвени со помош на преполимеризација со два поликарбонатни диоли (и двата со $M_{r}$ околу 1000) кои се разликуваат според составот на низите, хексаметилен-диизоцијанат и 1,4-бутан диол (за продолжување на низата) како почетни компоненти. Сите примероци имаат иста содржина на цврста фаза (30 w/w\%). Термогравиметрија заедно со диференцијална скенирачка калориметрија (TG-DSC) беа изведени за да се добијат информации за додадените органски глини и за термичка стабилност на подготвениот полиуретански еластомер. Следен е ефектот на бентонитот и нанополнилото монтморилонит врз процесот на деградација. Со деконволуција на изводот на термогравиметриските (DTG) криви беше утврдено дека термичката деградација на полиуретанските 
примероци се одвива во три процеси кои се преклопуваат. Деградационите кинетички параметри (енергијата на активација и редот на реакцијата) се пресметани врз основа на термичките податоци добиени од само еден степен на загревање.

Клучни зборови: полиуретански нанокомпозити базирани на поликарбонати; слоевити силикати; DTG; термичка стабилност

\section{INTRODUCTION}

The aliphatic polycarbonate-based polyurethanes (PC-PUs) are thermoplastics with a wide range of engineered application due to their microphase-separated structure, caused by the incompatibility of soft and hard phases. Since these elastomers are characterized by good biocompatibility and biostability, they have found an important medical application, for producing equipment and artificial tissues [1-5]. Due to their enhanced mechanical and thermal performances, PC-PUs can be also used as industrial parts and building materials [6-9]. In our previous work, the structure and thermal properties of polyurethane/organoclay nanocomposites obtained by prepolymerization were studied in detail [10]. The investigation of hydrogen-bonding formation and collecting the information on the nanometer-scale physical structures of the PC-PUs and their hybrids obtained by the two-step technique was done using Fourier transform infrared (FT-IR) spectroscopy and wide-angle X-ray diffraction (WAXD). The morphology of unfilled and filled materials influenced by microphase-separated state has been studied by small-angle Xray scattering (SAXS) and differential scanning calorimetry (DSC) measurements. In following research, the intercalation of montmorillonite and bentonite was determined. All methods have confirmed the existence of a heterogeneous microstructure with phase separation. Thermal properties (the glass transition temperature, the temperature of hard segments melting, and the recrystallization temperature) were influenced by the dispersion of nanofillers with layered structure [10].

It is well known that the addition of organoclays with a layered structure of nanopar- ticles to the polymer matrix can enhance thermal degradation of nanocomposites [11-15]. Many researchers have investigated the influence of hydrogen bonding and nanofiller content on thermal stability and degradation kinetics of PU mineral-reinforced materials using thermogravimetry [16-17]. Polyurethanes are relatively thermally unstable materials, and the decomposition temperature of the urethane bond depends on their composition and structure [18]. The degradation of polyurethane materials is caused by the breakage of urethane linkages, which can be achieved through three mechanisms that may occur simultaneously: dissociation into isocyanate and alcohol as its starting components, breaking of the urethane bonds with formation of primary amine and olefin, and splitting the urethane linkage to form secondary amine and carbon dioxide [19]. The incorporation of nanoparticles in a polymer matrix can lead to a change in the decomposition temperatures and degradation mechanism, causing the formation of products that differ both in quantity and identity compared to neat matrices [20].

The degradation of PUs is a complex process, which generally consists of at least two stages [21, 22]. The first one presents the decomposition of the hard segment, which involves the dissociation of polyurethane to chain extender and isocyanate. It is known that in this stage, the amount of residue is correlated with the amount of unreacted isocyanate in polymers [23]. The second step is assigned to depolycondensation and polyol degradation mechanisms and is affected by the soft-segment content $[24,25]$. The objective of the present research is focused on the investigation of the influence of the polycarbonate chain constitution and the addition of organically modified montmorillonite and 
bentonite $(1 w / w \%)$ on the thermal stability of elastomers obtained by prepolymerization. The mechanism of the decomposition was assessed using the extracted curves obtained by deconvolution of derivative thermogravimetric (DTG) data. The non-isothermal kinetic parameters (the reaction order and the activation energy) were determined using TG data at one heating rate.

\section{EXPERIMENTAL}

\subsection{Materials and polyurethane film preparation}

Aliphatic polycarbonate macrodiols with molecular mass around 1000 (PCDL T5651 and T4671) were kindly provided by Asahi Kasei Chemical Corporation. All characteristics of macrodiols were given by the supplier. For PCDL T5651: $\mathrm{OH}$ value: $111.4 \mathrm{mg} \mathrm{KOH} / \mathrm{g}$; water content: $0.0052 \mathrm{w} / \mathrm{w} \%$; viscosity at $50{ }^{\circ} \mathrm{C}$ : $1619 \mathrm{mPas}$. For PCDL T4671: OH value: 109.9 $\mathrm{mg} \mathrm{KOH} / \mathrm{g}$; water content $0.0072 w / w \%$; viscosity at $50{ }^{\circ} \mathrm{C}: 2388 \mathrm{mPas}$. The hexamethylenediisocyanate (HDI), 1,4-butane diol (1,4-BD), and the catalyst, dibutyltin dilaurate (DBTDL), used were all from Fluka. The catalyst solution was prepared in Marcol oil $(20 w / w \%)$. As a solvent, tetrahydrofuran (Sigma Aldrich) was applied. Organically modified montmorillonite (Cloisite ${ }^{\circledR} 15 \mathrm{~A}$, produced by Southern Clay Products, Inc.) and organically modified bentonite
(Bentonite for organic systems, BO, Fluka) were used as nanofillers.

Segmented polycarbonate-based polyurethane films were prepared by prepolymerization. During the two-step procedure, the ratio of $\mathrm{OH}$ groups from the diol and chain extender was kept constant $(R=1)$, while isocyanate component was added in slight excess $\left(\mathrm{NCO} / \mathrm{OH}_{\text {total }}=\right.$ 1.05). In the first step, tetrahydrofuran was added to the polycarbonate diol, then DBTDL (catalyst concentration was $0.05 \mathrm{w} / \mathrm{w} \%$ ). Then the pertinent excess of HMDI was added, and the mixture was stirred for $24 \mathrm{~h}$ at room temperature. The viscosity of the system increased due to the NCO encapped prepolymer formation. As a final step, the chain extender was added to the reaction system, mixed, and degassed in order to remove residual bubbles. Finally, the prepared reactive system was spread on a polypropylene sheet using a ruler (slot width $500 \mu \mathrm{m}$ ) and left for $24 \mathrm{~h}$ at room temperature in an inert atmosphere for the reaction of BD with the prepolymer and for gradual solvent evaporation. The sample preparation was finalized by post curing at 90 ${ }^{\circ} \mathrm{C}$ for $1 \mathrm{~h}$. For the synthesis of hybrid materials, the procedure was the same, except of the first step, where the organolayer silicate (bentonite and montmorillonite) nanoparticles were left to be dispersed in the mixture of polycarbonate diol and solvent for $48 \mathrm{~h}$. The code and description of prepared polyurethane elastomers and their nanocomposites are given in Table 1.

Table 1

The sample code and composition of obtained PC-PUs and their nanocomposites

\begin{tabular}{ccc}
\hline \hline Sample code & PC diol & Nanofiller $(1 \mathrm{w} / \mathrm{w} \%)$ \\
\hline $5651 / 0$ & 5651 & - \\
$5651 / \mathrm{BO}$ & 5651 & bentonite \\
$5651 / 15 \mathrm{~A}$ & 5651 & montmorillonite \\
$4671 / 0$ & 4671 & - \\
$4671 / \mathrm{BO}$ & 4671 & bentonite \\
$4671 / 15 \mathrm{~A}$ & 4671 & montmorillonite \\
\hline \hline
\end{tabular}




\subsection{Thermogravimetry coupled with} differential scanning calorimetry (TG-DSC analysis)

The thermal decomposition of the samples was studied by simultaneous TG/DSC measurements using the TA Instruments SDT Q600 thermal analyzer. The measurements were performed from room temperature to $450{ }^{\circ} \mathrm{C}$ in flowing-nitrogen atmosphere $(100$ $\mathrm{cm}^{3} / \mathrm{min}$ ), with a heating rate of $20{ }^{\circ} \mathrm{C} / \mathrm{min}$ and sample masses of about $3 \mathrm{mg}$, employing an open alumina crucible and a corresponding empty referent crucible.

\section{RESULTS AND DISCUSSION}

The structure of PC-PUs, prepared by a two-step procedure under DBTDL-catalyzed conditions, with separated (soft and hard) domains is shown in Figure 1. Segmented aliphatic polyurethanes consist of alternating crystallizable hard segments (formed from the chain extender and diisocyanate component) and flexible soft segments (made from polycarbonate diol).
The presence of hard domains in the structure is directly related to the physical properties of segmented polyurethane materials and connected to their thermal stability [26]. By introducing organoclays in polymer matrix, reactions between hard domains and nanofillers modify the thermal behavior of the materials.

\subsection{Thermal stability and decomposition of the unfilled and filled PU materials}

Thermogravimetric analysis coupled with DSC (TG-DSC) of the polycarbonate-based polyurethanes and their reinforced elastomers has been performed to obtain information on the influence of macrodiol type and the presence of nanofillers on the thermal decomposition of the materials. In order to gain a better insight into the thermal behavior of novel polyurethanes, the thermal stability of each starting component was studied also. TG and DTG curves of polycarbonate diols 5651 and 4671 and the diisocyanate and chain extender (hard segments) are shown in Figure 2.

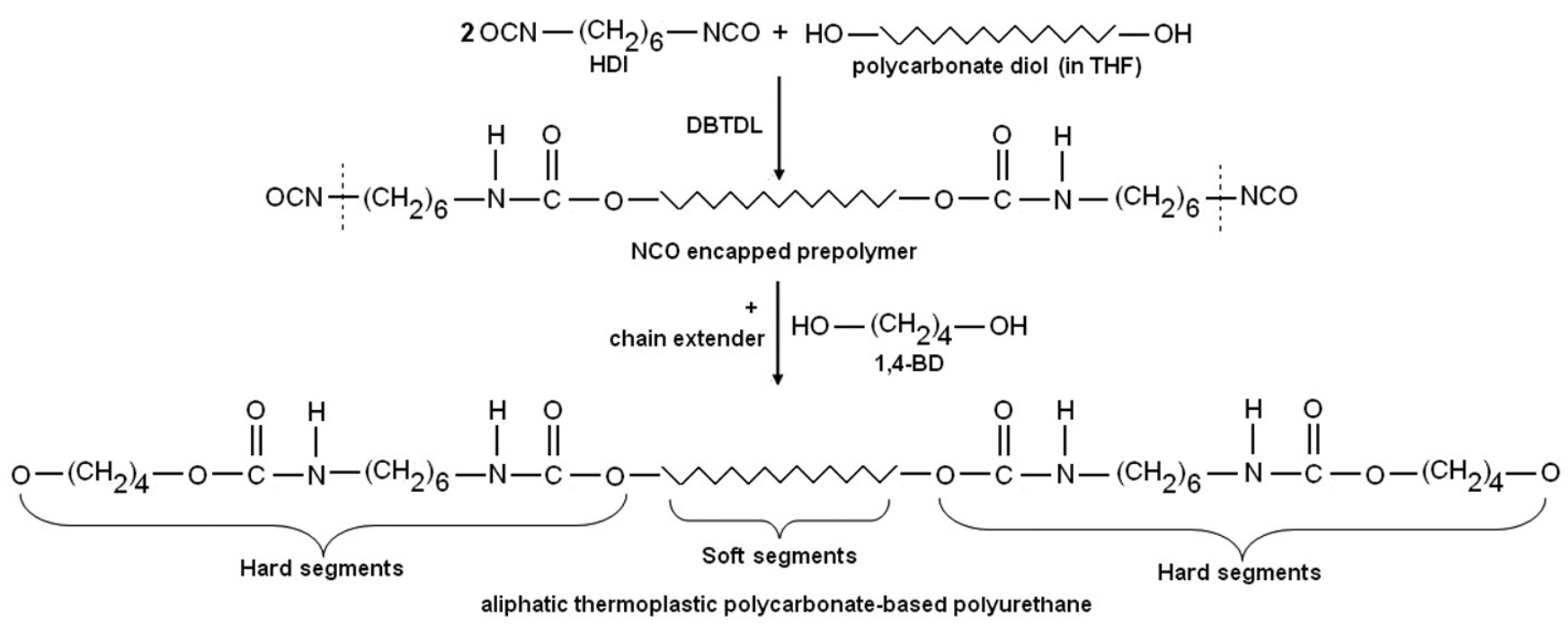

Fig. 1. Scheme of the prepolymerization used for the preparation of polycarbonate-based polyurethanes 

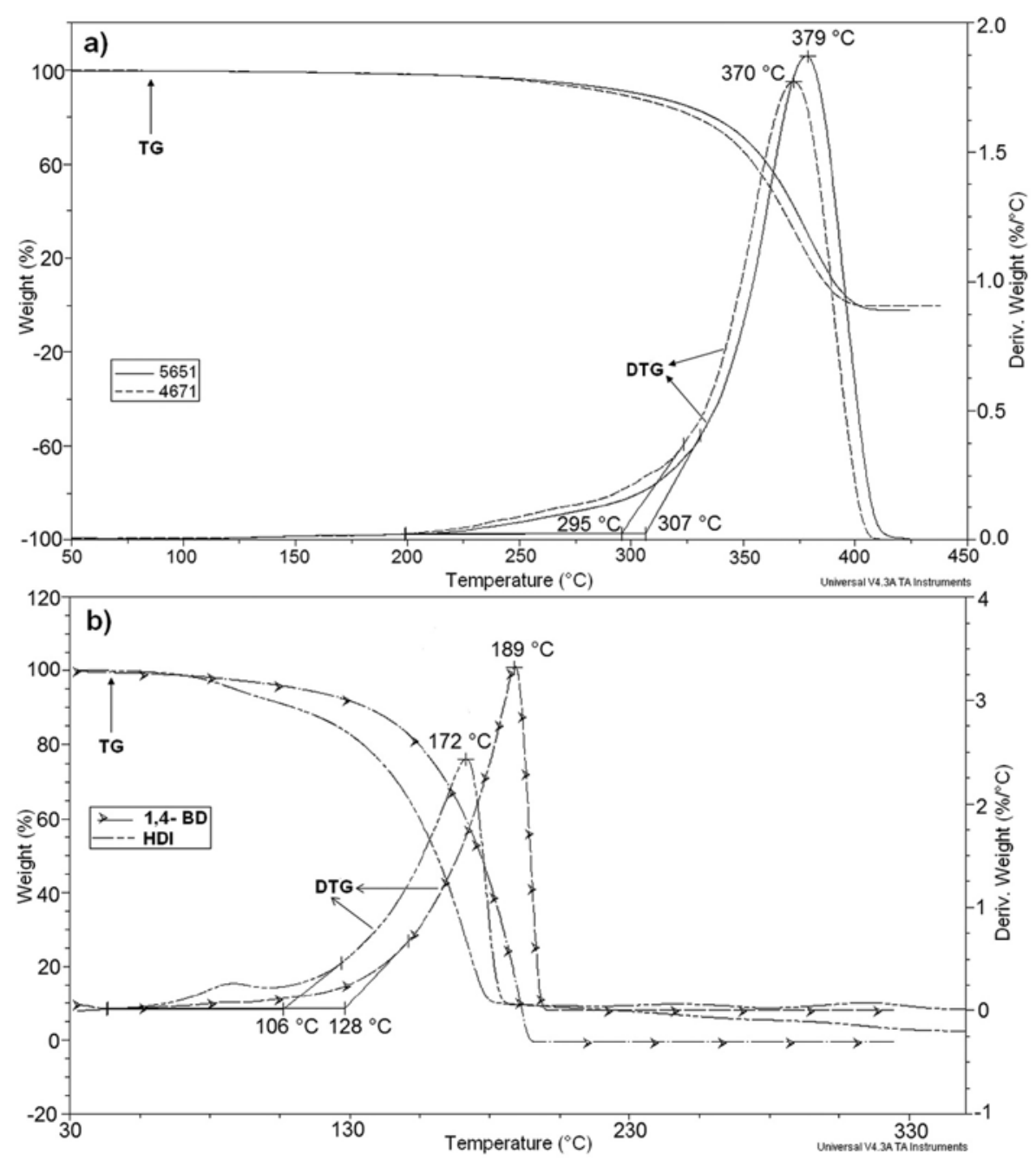

Fig. 2. TG and DTG curves of the starting compounds: a) pure polycarbonate diols; b) pure chain extender $(1,4-\mathrm{BD})$ and pure diisocyanate component (HDI)

Figure 2 shows that the thermal stability of polycarbonate diols is significantly higher than the reactive components used for hardsegment formation. The thermal stability of polycarbonate diol 5651 is higher by $10{ }^{\circ} \mathrm{C}$ compared to the stability of diol type 4671 (onset for diol 5651 is $307{ }^{\circ} \mathrm{C}$; onset for diol 4671 is $295{ }^{\circ} \mathrm{C}$; see Figure 2a). The difference in the thermal stabilities of HDI and 1,4-BD is somewhat higher (for HDI onset is $106^{\circ} \mathrm{C}$, and for BD onset is $128^{\circ} \mathrm{C}$; see Figure $2 b$ ).

As derivative thermogravimetric (DTG) curves are more sensitive than TG curves, the decomposition of polyurethanes and their nanocomposites based on PC diol type 5651 or PC diol type 4671 is presented by the corresponding DTG curves in Figures $3 a$ and $3 b$.

The onset temperature is about the same for all samples: $T_{\mathrm{o}}=298 \pm 3{ }^{\circ} \mathrm{C}$. At the lower temperature, a small weight loss of $\sim 4 \%$ is observed. The shape of DTG curves refers to a complex decomposition pattern involving several overlapped processes. The presence of nanofillers does not affect the onset temperature. However, it shifts the peak temperature to higher values. This means that it has an effect on the decomposition rate. Namely, nanofillers slow down the decomposition of the elastomers. The decomposition is not complete, and above 400 

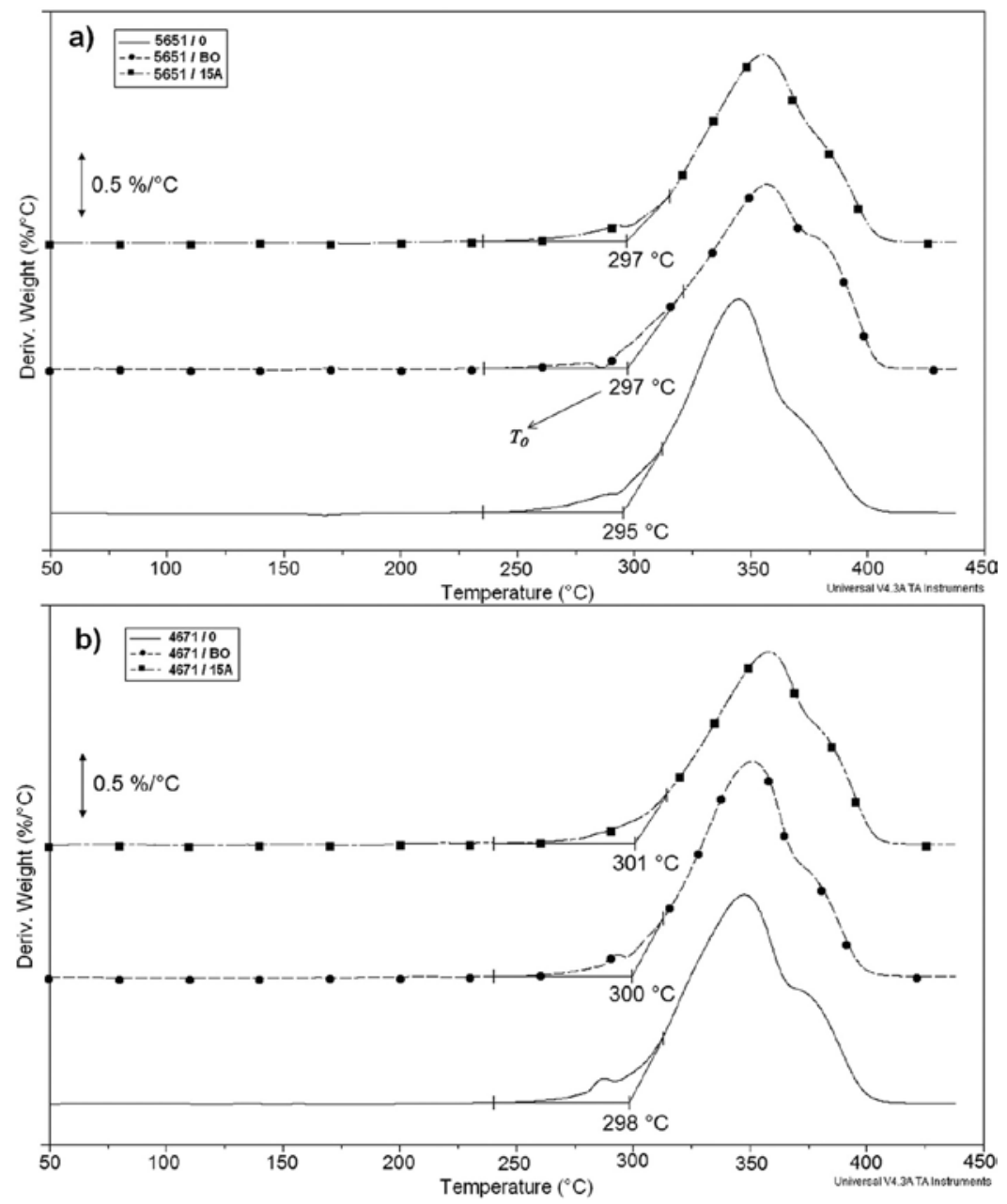

Fig. 3. DTG curves of unfilled PU elastomers and filled with $1 w / w \%$ of organoclays, based on a) PC diol 5651 and b) PC diol 4671

${ }^{\circ} \mathrm{C}$, some carbonaceous char residue is left. The amount of the residue in materials with nanofillers is evidently higher because neither montmorillonite nor bentonite is volatile. The increase of char amount of nanocomposites compared to unfilled elastomers is somewhat higher than expected on the basis of the amount of the additive $(1 w / w \%)$, indicating that clay particles affect the degradation pathway [20]. The nanoparticles generate a "barrier effect," which causes a delay in the release of volatile products in comparison to the pure polymer [27]. The change in the decomposition rate could be the consequence of an extended H-bond network in the elastomers or/and because the small filler molecules slow down the heat transfer between the layers (see DTG peaks in Figure 3). Thermal enhancement by montmorillonite dispersion in polymer matrix was already observed [28-30]. The addition of bentonite to PUs also slightly improved thermal stability.

In DSC curves (Figure 4) the effect of nanofillers is even more emphasized. The influence of the nanofillers on the decomposition mechanism is clearly seen. The endothermic decomposition in filled polymers consists of better separated processes, which are less endothermic compared to the corresponding unfilled elastomers. The nanofillers affect the decomposition pattern of elastomers more with diol type 5651 than those containing type 4671. 

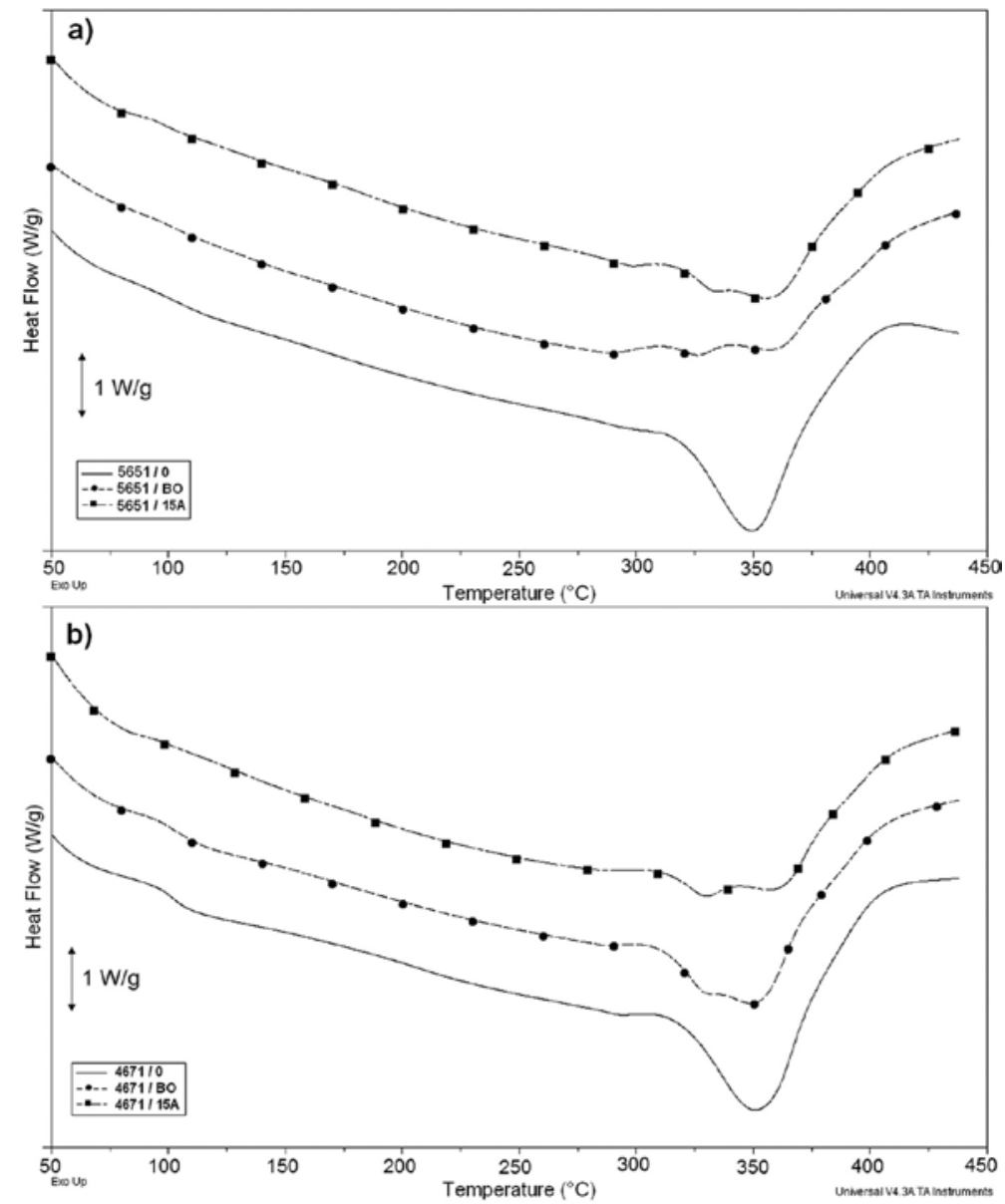

Fig. 4. DSC curves of polyurethane elastomers and their nanocomposites based on a) PC diol type 5651 and b) PC diol type 4671

DSC curves of unfilled and filled samples before decomposition temperature show one very small (more visible in PUs based on PC diol type 4671) endothermic change near $90^{\circ} \mathrm{C}$, which may be related to the melting of hard segments.

The detailed inspection of DTG curves suggests that the decomposition consists of multiple processes, taking place simultaneously and which can be separated by deconvolution using the Gaussian equation. Figure 5 shows that deconvolution of DTG peaks for the PU series based on diol type 5651 . The degradation profiles in nitrogen atmosphere exhibit three peaks (steps), which are described by the peak area $(\Delta m)$ and peak maximum $\left(T_{d}\right)$. It has been reported that the amount of weight lost at each degradation stage may be used as a quantitative measurement of the hard (HS) and soft (SS) content in the segmented
PUs [31]. On the basis of the contribution of each degradation step with corresponding peak maximum, the influence of the macrodiol type and organoclay addition on the decomposition pattern might be explained. The first stage, detected at low temperature, is connected with the HS degradation. The two high-temperature steps are probably associated with the degradation of the soft segments, due to the building units in the macrodiols. The chains of both polycarbonate diols consist of hexamethylene (C6) and tetramethylene (C4) units between carbonate groups, but in various ratios. Similar data were found in literature [32]. The results of the numerical analysis of the polyurethane materials decomposition are listed in Table 2. The appearance of HS degradation at low temperatures is most probably due to the low thermal stability of the hard-segment building 


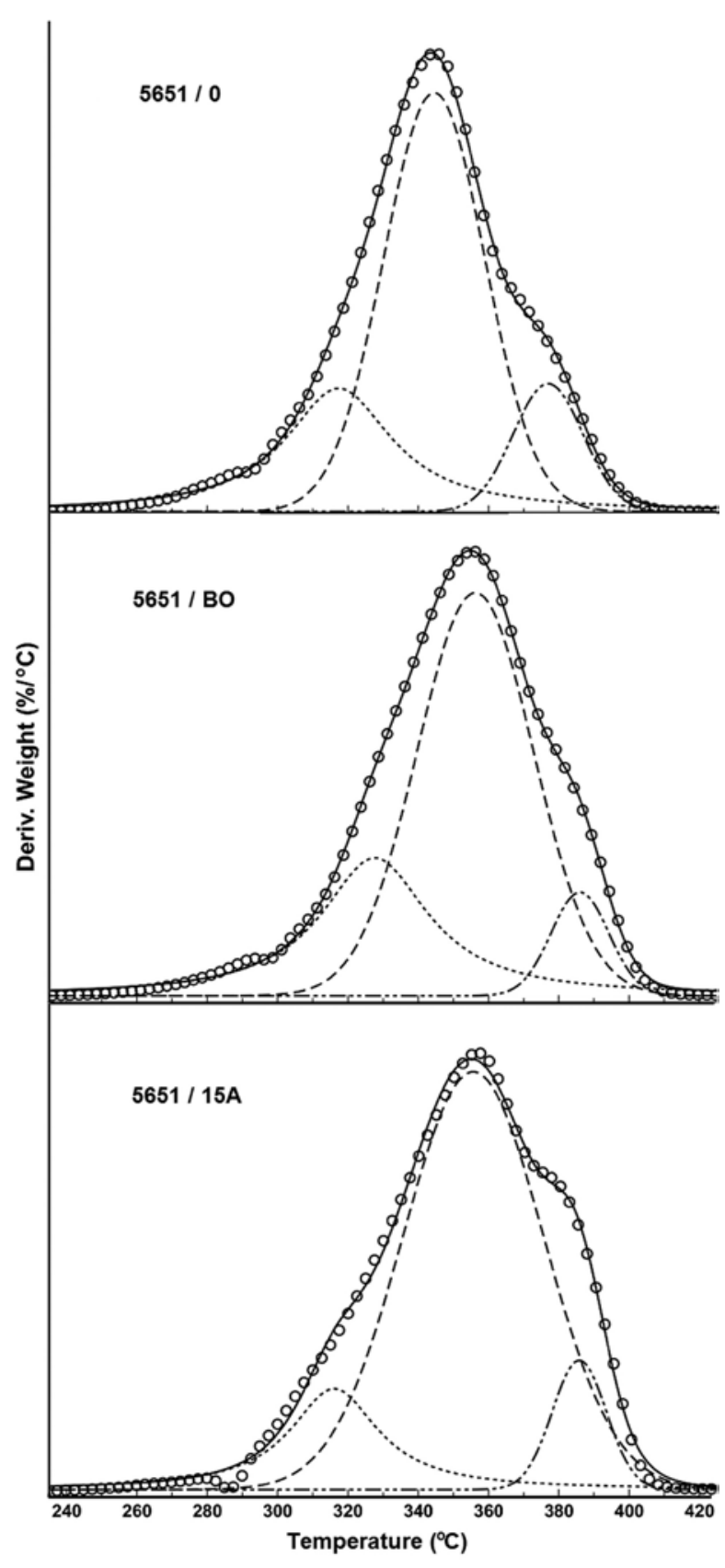

Fig. 5. Determination of multiple decomposition stages (position and area) by deconvolution of DTG curves for polyurethanes based on PC diol type 5651: pure $(5651 / 0)$, with $1 w / w \%$ of bentonite (5651/ BO), and with $1 w / w \%$ of montmorillonite (5651/15A)

units (Figure 2b). The presence of the two last high superposed DTG maxima in polyurethanes and their nanocomposites may be the result of the high thermal stability of the pure polycarbonate diols (Figure 2a).
The average value of the first decomposition peak contribution, $A_{1}$, is 28.8 , and it is related to the hard-segment content in all samples calculated to be $30 \mathrm{w} / \mathrm{w} \%$. The sum of the contributions of two other decomposition steps $\left(A_{2}\right.$ and $\left.A_{3}\right)$ is connected to the soft-segment content (70 $w / w \%)$. Results obtained using deconvolution of DTG peaks show that this method might be suitable for quantitative determination of hard and soft segments in segmented PC-PUs. The addition of $1 w / w \%$ of bentonite or montmorillonite slightly shifts the temperature of each degradation step to a higher value (Figure $6)$. The temperature increase of three decomposition stages is more pronounced for polyurethanes based on PC diol type 5651.

\subsection{Kinetics of thermal degradation of a series of segmented unfilled and filled polyurethanes}

The thermal degradation kinetics of segmented unfilled and filled polyurethanes was also studied. The correct interpretation of the kinetic parameters of the decomposition obtained from experimental data is not an easy task, and it significantly depends on the method used for the calculation [23]. Several integral and differential methods could be applied for the determination of kinetic parameters of the thermal decomposition using thermogravimetric data $[33,34]$. In this work, data obtained at only one heating rate $\left(20{ }^{\circ} \mathrm{C} / \mathrm{min}\right.$ ) has been used for the determination of the reaction order and activation energy. First, TG curves were transformed into conversion vs. temperature curves using Equation 1:

$$
\alpha(T)=\frac{W_{0}-W_{T}}{W_{0}-W_{\infty}}
$$

where $\alpha$ is the degree of conversion, $W_{0}$ is the initial weight, $W_{\infty}$ is the final weight, and $W_{T}$ is the weight at temperature $T(\mathrm{~K})$.

The activation energy and the reaction order were determined using the non-isothermal direct differential method presented by Equation 2: 
$\mathrm{T}$ a b 1 e 2

Data describing the degradation stages obtained by deconvolution of polyurethanes DTG curves

\begin{tabular}{|c|c|c|c|c|c|c|}
\hline \multirow[b]{2}{*}{ Sample code } & \multicolumn{2}{|c|}{ First degradation step } & \multicolumn{2}{|c|}{ Second degradation step } & \multicolumn{2}{|c|}{ Third degradation step } \\
\hline & $\begin{array}{c}\text { Peak } \\
\text { area } \\
A_{1}(\%)\end{array}$ & $\begin{array}{c}\text { Peak } \\
\text { maximum } \\
T_{d, 1}\left({ }^{\circ} \mathrm{C}\right)\end{array}$ & $\begin{array}{c}\text { Peak } \\
\text { area } \\
A_{2},(\%)\end{array}$ & $\begin{array}{c}\text { Peak } \\
\text { maximum } \\
T_{d^{\prime} 2}\left({ }^{\circ} \mathrm{C}\right)\end{array}$ & $\begin{array}{c}\text { Peak } \\
\text { area } \\
A_{3}(\%)\end{array}$ & $\begin{array}{c}\text { Peak } \\
\text { maximum } \\
{ }^{\prime} T_{d^{\prime} 3}\left({ }^{\circ} \mathrm{C}\right)\end{array}$ \\
\hline $5651 / 0$ & 27.6 & 317 & 59.8 & 345 & 12.6 & 377 \\
\hline $5651 / \mathrm{BO}$ & 29.4 & 328 & 62.6 & 356 & 8.0 & 386 \\
\hline $5651 / 15 \mathrm{~A}$ & 32.0 & 329 & 53.6 & 359 & 14.4 & 386 \\
\hline $4671 / 0$ & 22.0 & 319 & 71.0 & 345 & 7.0 & 375 \\
\hline 4671 / BO & 36.5 & 324 & 49.3 & 349 & 14.0 & 379 \\
\hline $4671 / 15 \mathrm{~A}$ & 25.7 & 325 & 67.5 & 358 & 6.8 & 387 \\
\hline average value & 28.8 & 324 & 60.7 & 352 & 10.5 & 382 \\
\hline st. deviation & 5.1 & 5.0 & 8.2 & 7.0 & 3.7 & 5.0 \\
\hline
\end{tabular}

$$
\frac{d \alpha}{d T}=\frac{A}{\beta} e^{-\frac{E a}{R T}} f(\alpha)
$$

where $A$ is the preexponential factor, $R$ is the gas constant, $\beta$ is the heating rate, and $E_{a}$ is the energy of activation. For most of the reactions, $f(\alpha)$ is usually [35] defined as:

$$
f(\alpha)=(1-\alpha)^{n}
$$

where $n$ is the reaction order.

Introducing the form for $f(\alpha)$ and applying natural logarithm, Equation 2 can be transformed into

$$
\ln \frac{\frac{d \alpha}{d T}}{(1-\alpha)^{n}}=\ln \frac{A}{\beta}-\frac{E_{a}}{R T}
$$

The left-hand side (including the reaction order $n$ ) of Equation 4 versus $1 / T$ gives a line. Its slope gives the activation energy $\left(E_{a}\right)$, while the intercept is equal to the frequency factor $(A)$. In the first step, the reaction order was determined. The following approach was applied: the correlation coefficient between the left-hand side of Equation 5 and $1 / T$ was expressed as a function of the reaction order, which is shown for the unfilled elastomer based on PC diol type 5651 (Figure 6). In all cases, the achieved correlation coefficient was high (above 0.99 ). The value of the reaction order was chosen on the basis of the maximum correlation coefficient. With the determined reaction order, the slope of the plot of $\ln \left((d \alpha / d t) /(1-\alpha)^{n}\right)$ vs. $1 / \mathrm{T}$ gives $E_{a}$ (Figure 7 and Table 3 ).

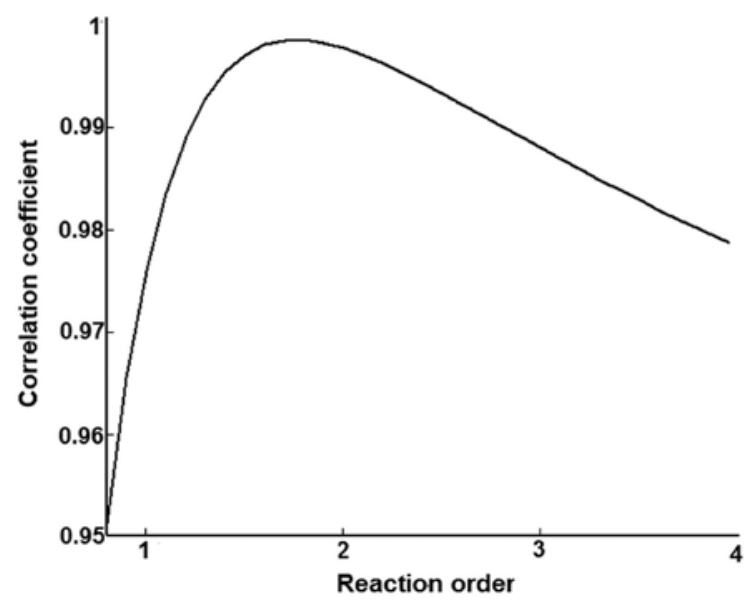

Fig. 6. Correlation coefficient dependence on the reaction order for unfilled polyurethane elastomer based on PC 


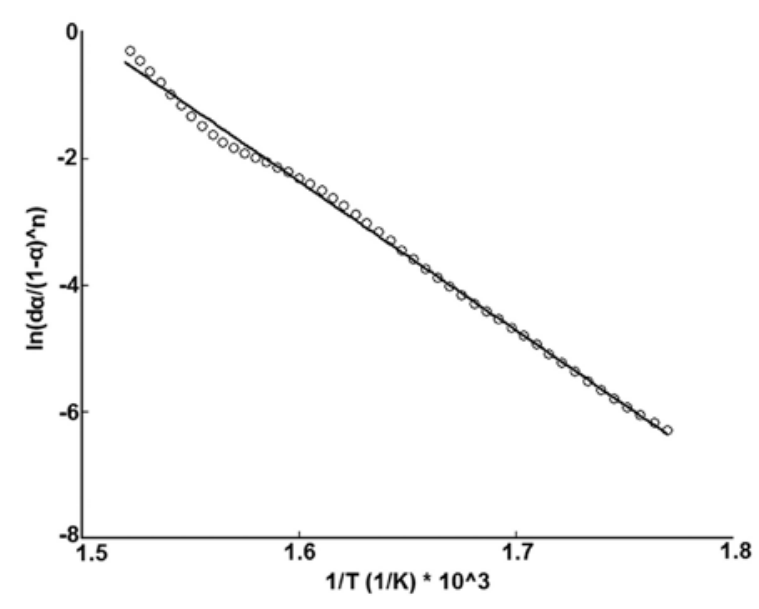

diol type 5651

Fig. 7. Dependence of the left side of Eq. 4 on reciprocal temperature for unfilled polyurethane elastomer based on PC diol type 5651

Table 3

Kinetic parameters
(reaction order and activation energy) of the
degradation process of polycarbonate-based
polyurethanes and their hybrid materials

\begin{tabular}{lcc}
\hline Sample code & $\begin{array}{c}\text { Reaction order, } \\
n\end{array}$ & $\begin{array}{c}\text { Activation energy } \\
E_{\mathrm{a}}(\mathrm{kJ} / \mathrm{mol})\end{array}$ \\
\hline 5651 / 0 & 1.76 & 195.5 \\
$5651 / \mathrm{BO}$ & 1.54 & 182.2 \\
$5651 / 15 \mathrm{~A}$ & 1.50 & 167.9 \\
$4671 / 0$ & 1.53 & 186.3 \\
$4671 / \mathrm{BO}$ & 1.70 & 185.1 \\
$4671 / 15 \mathrm{~A}$ & 1.35 & 164.2 \\
\hline
\end{tabular}

The variation in reaction order and activation energy values confirmed the complexity of the PC-PUs thermal degradation mechanism caused by the addition of organoclay nanoparticles. As no regularity was found in the values of either the reaction order or activation energy, the effect of nanoparticles on the thermal decomposition of polymers was mainly evaluated from the decomposition temperatures recorded during the thermogravimetric analysis.

\section{CONCLUSIONS}

A series of all aliphatic polycarbonatebased polyurethanes and their hybrid materials, with $30 \mathrm{w} / \mathrm{w} \%$ of hard segments, were synthesized using prepolymerization. Mineral-reinforced nanocomposites were obtained by $1 \mathrm{w} / \mathrm{w}$ $\%$ addition of organically modified bentonite and montmorillonite. It was determined that soft segments (polycarbonate diols) possess significantly better thermal stability than hard-segment building units consisting HDI and 1,4-BD blocks, with higher values for the decomposition onset and DTG peak temperatures by about $200{ }^{\circ} \mathrm{C}$. The onset temperatures of prepared polyurethanes and their hybrid materials were found to be 298 $\pm 3{ }^{\circ} \mathrm{C}$. The influence of macrodiol choice and organoclay addition was determined by deconvolution of DTG curves using the Gaussian equation. A detailed inspection of obtained Gaussian curves suggested that thermal degradation processes consist of three steps, taking place simultaneously in temperatures ranging from 300 to $410{ }^{\circ} \mathrm{C}$. The first stage, detected at low temperature, is connected with hard-segment degradation, and the two high-temperature steps are probably associated with the degradation of soft segments, due to the different chain constitutions of the macrodiols used. The addition of nanofillers shifted the temperatures of all decomposition stages higher, causing a thermal stability enhancement of prepared materials due to the interaction between layered silicates and PU matrix. Degradation kinetics (activation energy and reaction order) was determined, applying the proposed method based on only one heating rate. Obtained variation of kinetic parameters has confirmed the complexity of the thermal degradation mechanism of prepared nanostructured polyurethanes.

Acknowledgment. This work was financed by the Ministry of Education and Science of the Republic of Serbia (Grants No. III45022 and 172014). The authors from Prague wish to acknowledge the Grant Agency of the Czech Republic (Czech Science Foundation, Project No. P108/10/0195). 


\section{REFERENCES}

[1] M. Špírková, Polyurethane elastomers made from linear polybutadiene diols, J. Appl. Polym. Sci., 85, 84-91 (2002).

[2] M. Špírková, L. Matějka, B. Meissner, J. Pytela, Polybutadiene-based polyurethanes with controlled properties: preparation and characterization, $J$. Appl. Polym. Sci., 77, 381-389 (2000).

[3] Khan, N. Smith, E. Jones, D. S. Finch, R. E. Cameron, Analysis and evaluation of a biomedical polycarbonate urethane tested in an in vitro study and an ovine arthroplasty model. Part I: Materials selection and evaluation, Biomaterials, 26, 621631 (2005).

[4] A.Eceiza, M.Larranaga, K. de la Caba, G. Kortaberria, C. Marieta, M. A. Corcuera, I. Mondragon, Structureproperty relationships of thermoplastic polyurethane elastomers based on polycarbonate diols, J. Appl. Polym. Sci., 108, 3092-3103 (2008).

[5] K. Kojio, S. Kugumiya, Y. Uchibaq, Y. Nishino, M. Furukawa, The microseparated structure of polyurethane bulk and thin flms, Polym. J., 41, 118-124 (2009).

[6] M. Špírková, A. Strachota, M. Urbanová, J. Baldrian, J. Brus, M. Šlouf, A. Kuta, Z. Hrdlička, Structural and surface properties of novel polyurethane films, Mater. Manuf. Process., 24, 1185-1189 (2009).

[7] K. C. Kim, S. B. Bae, J. R. Ahn, I. J. Chung, Structure-property relationships of hydroxyterminated polyether based polyurethane network, Polym. Bull., 61, 225-233 (2008).

[8] M.C. Tanzi, D. Mantovani, P. Petrini, R. Guidoin, G. Laroche, Chemical stability of polyether urethanes versus polycarbonate urethanes, $J$. Biomed. Mat. Res., 36, 550-559 (1997).

[9] S. Velankar, S. L. Cooper, Microphase separation and rheological properties of polyurethane melts. 2. Effect of block incompatibility on the microstructure, Macromolecules, 33, 382-394 (2000).

[10] J. Pavličević, M. Špírková, M. Jovičić, O. Bera, R. Poręba, J. Budinski-Simendić, The structure and thermal properties of novel polyurethane/ organoclay nanocomposites obtained by prepolymerization, Compos. Part B Eng., 45, 232238 (2013).

[11] J. K. Pandey, K. R. Reddy, A. P. Kumar, R. P. Singh, An overview on the degradability of polymer nanocomposites, Polym. Degrad. Stab., 88, 234-250 (2005).

[12] A. Leszczynska, J. Njuguna, K. Pielichowski, J. R. Banerjee, Polymer/montmorillonite nanocomposites with improved thermal properties: Part I. Factors influencing thermal stability and mechanisms of thermal stability improvement, Thermochim. Acta., 453, 75-96 (2007).

[13] A. Leszczynska, J. Njuguna, K. Pielichowski, J. R. Banerjee, Polymer/montmorillonite nanocomposites with improved thermal properties: Part II. Thermal stability of montmorillonite nanocomposites based on different polymeric matrixes, Thermochim. Acta., 454, 1-22 (2007).

[14] M. Špírková, J. Pavličević, A. Strachota, R. Poręba, O. Bera, L. Kaprálková, J. Baldrian, M. Šlouf, N. Lazić, J. Budinski-Simendić, Novel polycarbonate-based polyurethane elastomers: Composition-property relationship, Eur. Polym. $J ., 47,959-972(2011)$.

[15] J. Pavličević, M. Špirková, A. Strachota, K. Mészáros Szécsényi, N. Lazić, J. BudinskiSimendić, The influence of montmorillonite and bentonite addition on thermal properties of polyurethanes based on aliphatic polycarbonate diols, Thermochim. Acta., 509, 73-80 (2010).

[16] M. N. Satheesh Kumar, Siddaramaiah, Thermo gravimetric analysis and morphological behavior of castor oil based polyurethane-polyester nonwoven fabric composites, J. Appl. Polym. Sci., 106, 3521-3528 (2007).

[17] F. Suhara, S. K. N. Kutty, G. B. Nando, Rheological properties of short polyester fiber- polyurethane elastomer composite Polym. Plast. Tech. Eng., 36, 399-409 (1997).

[18] S. Solarski, S. Benali, M. Rochery, E. Devaux, M. Alexandre, F. Monteverde, P. Dubois, Synthesis of a polyurethane/clay nanocomposite used as coating: Interactions between the counterions of clay and the isocyanate and incidence on the nanocomposite structure, J. Appl. Polym. Sci., 95, 238-244 (2005).

[19] Z. Petrović, J. Ferguson, Polyurethane elastomers, Prog. Polym. Sci., 16, 695-836 (1991).

[20] K. Chrissafis, D. Bikiaris, Can nanoparticles really enhance thermal stability of polymers? Part I: An overview on thermal decomposition of addition polymers, Thermochim. Acta., 523, 1-24 (2011).

[21] N. Grassie, G. Scott, Polymer degradation and stability, Cambridge, University Press, London, 1985. 
[22] M. G. Lu, J. Y. Lee, M. J. Shim, S. W. Kim, Thermal degradation of film cast from aqueous polyurethane dispersions J. Appl. Polym. Sci., 85, 2552-2558 (2002).

[23] Z. S. Petrović, Z. Zavargo, J. H. Flynn, W. J. Macknight, Thermal degradation of segmented polyurethanes, J. Appl. Polym. Sci., 51, 1087-1095 (1994).

[24] X. Gao, B. Zhou, Y. Guo, Y. Zhu, X. Chen, Y. Zheng, W. Gao, X. Ma, Z. Wang Z, Synthesis and characterization of well-dispersed polyurethane/ $\mathrm{CaCO}_{3}$ nanocomposites, Colloid. Surface. A., 371, $1-7$ (2010).

[25] I. Javni, Z. S. Petrović, A. Guo, R. Fuller, Thermal stability of polyurethanes based on vegetable oils, J. Appl. Polym. Sci., 77, 1723-1734 (2000).

[26] J. Jin, M. Song, K. J. Yao, A MTDSC analysis of phase transition in polyurethane-organoclay nanocomposites, Thermochim. Acta., 447, 202208 (2006).

[27] S. Y. Moon, J. K. Kim, C. Nah, Y. S. Lee, Polyurethane/montmorillonite nanocomposites prepared from crystalline polyols, using 1,4-butanediol and organoclay hybrid as chain extenders, Eur. Polym. J., 40, 1615-1621 (2004).

[28] Y. I. Tien, K. H. Wei, Thermal transitions of montmorillonite/polyurethane nanocomposites, $J$. Polym. Res., 7, 245-250 (2000).

[29] H. Jiang, J. Qian, Y.Bai, M. Fang, X. Qian, Preparation and properties of polyurethane/montmorillonite nanocomposites cured under room temperature, Polym. Composite., 27, 470-474 (2006).

[30] Y. I. Tien, K. H. Wei, The effect of nano-sized silicate layers from montmorillonite on glass transition, dynamic mechanical, and thermal degradation properties of segmented polyurethane, J. Appl. Polym. Sci., 86, 1741-1748 (2002).

[31] L. Gomes Lage, Y. Kawano, Thermal degradation of biomedical polyurethanes. A kinetic study using high-resolution thermogravimetry, J. Appl. Polym. Sci., 79, 910-919 (2001).

[32] R. A. Azzam, S. K. Mohamed, R. Tol, V. Everaert, H. Reynaers, B. Goderis, Synthesis and thermomechanical characterization of high performance polyurethane elastomers based on heterocyclic and aromatic diamine chain extenders, Polym. Degrad. Stabil., 92, 1316-1325 (2007).

[33] H. Nishizaki, K. Yoshida, J. H. Wang, Comparative study of various methods for thermogravimetric analysis of polystyrene degradation, J. Appl. Polym. Sci., 25, 2869-2877 (1980).

[34] D. Filip, D. Macocinschi, S Vlad, Thermogravimetric study for polyurethane materials for biomedical applications, Comp. Part-Eng. B., 42, 1474-1479 (2011).

[35] Z. Petrović, Z. Zavargo, Reliability of methods for determination of kinetic parameters from thermogravimetry and DSC measurements, $J$. Appl. Polym. Sci., 32, 4353-4367 (1986). 